\title{
Evaluation of different varieties of Okra (Abelmoschus esculentus L.) under the climatic conditions of Tandojam
}

Shah Faisal ${ }^{1}$, Fazal Muhammad Bangulzai ${ }^{*}$, Nazeer Ahmed Alizai $^{2}$, Shabeer Ahmed ${ }^{2}$, Abdul Rauf Zehri², Shah Alam², Abdul Ghaffar ${ }^{2}$, Syed $\mathrm{Shah}^{2}$, Najeebullah ${ }^{2}$, Zehri Khan ${ }^{3}$, Shah Pasand ${ }^{3}$ and Sibghatullah ${ }^{3}$

1. Sindh Agriculture University Tandojam, Sindh-Pakistan

2. Agriculture Research Institute (A.R.I) Sariab Quetta, Balochistan-Pakistan

3. Horticulture Research Institute BARDC (PARC) Khuzdar-Pakistan

*Corresponding author's email: fazalbangulzai786@gmail.com

Citation

Shah Faisal, Fazal Muhammad Bangulzai, Nazeer Ahmed Alizai, Shabeer Ahmed, Abdul Rauf Zehri, Shah Alam, Abdul Ghaffar, Syed Shah, Najeebullah, Zehri Khan, Shah Pasand and Sibghatullah. Evaluation of different varieties of Okra (Abelmoschus esculentus L.) under the climatic conditions of Tandojam. Pure and Applied Biology. Vol. 10, Issue 3, pp878-885. http://dx.doi.org/10.19045/bspab.2021.100090

\begin{tabular}{llll}
\hline Received: 18/08/2020 & Revised: 29/11/2020 & Accepted: 18/12/2020 & Online First: 30/12/2020 \\
\hline
\end{tabular}

\section{Abstract}

In order to evaluate the okra varieties under climatic conditions of Tandojam, the present experiment was conducted during 2015. The okra varieties included Sabz Pari, Punjab Selection, Anmol, Sharmeeli and Anamika. The observations were recorded on plant height $(\mathrm{cm})$, branches plant $^{-1}$, pods plant ${ }^{-1}$, single pod weight $(\mathrm{g})$, weight of pods plant ${ }^{-1}$, pods length $(\mathrm{cm})$ and pod yield $\left(\mathrm{kg} \mathrm{ha}^{-1}\right)$. The summary of the results are presented that all the studied indices were remarkably higher in variety 'Sabz Pari' having plant height $(87.47 \mathrm{~cm})$, branches plant ${ }^{-1}\left(5.66\right.$ plant $\left.^{-1}\right)$, pods plant $^{-1}$ (28.37 plant $\left.^{-1}\right)$, single pod weight (15.15 g), weight of pods plant ${ }^{-1}$ (252.67 plant $\left.^{-1}\right)$, pods length $(6.37 \mathrm{~cm})$ and pod yield $\left(12733 \mathrm{~kg} \mathrm{ha}^{-1}\right)$. Apart from the most superior performance of variety Sabz Pari, Punjab Selection, Anmol and Sharmeeli, also showed good average performance, but least values for all the studied traits were determined for variety 'Anamika. Statistical analysis indicates significant difference $(\mathrm{P}<0.05)$ for all studied parameters among the okra varieties. In conclusion, the variety Sabz Pari produced highest pod yield followed by variety 'Punjab Selection' 'Anmol' and 'Sharmeeli', while least figure for pod yield was examined in okra variety 'Anamika.

Keywords: Climatic condition; Growth; Okra; Production; Varieties; Yield

\section{Introduction}

Okra (Abelmoschus esculentus (L.) also known as lady's finger, Bhindi belonging to the family Malvaceae with somatic chromosome number $2 n=130$. It is basically self-pollinated crop, though essentially selfpollinated because of its showy corolla, the possibility of cross-pollination by insects cannot be ruled out. Consequently, cross pollination to the extent of 4.0-19.0 per cent with maximum of 42.2 per cent is noticed with the insect assisted pollination. Okra is an important vegetable crop, it is widely distributed and cultivated in tropics and 
subtropics of the world for its tender, delicious green fruits which are cooked, canned and consumed in various forms [1]. The crop is suitable for cultivation as a garden crop as well as on large commercial farms [2]. It is consumed by almost all the Sudanese people either as green immature pods (fried or cooked or in soup or stews) or sun dried and ground into a powdery form locally known as wieka" which is used as an ingredient in the preparation of a favorable Sudanese molah [3].

Fruit yield in okra is a complex trait that is governed by several yield components that are interrelated. The significance of number of pods per plant, early flowering and fruit weight in determining fruit yield in okra cultivars has been widely investigated by several workers [4-7]. Compared the yield performance of a local variety and an improved cultivar in Mubi and found that the improved cultivar was superior to the local in terms of pod yield [8].

The crop yields obtained in Pakistan are lesser than the existing potential due to soil deficiency in most of the nutrients required for plant growth and fruit development. Because of soil nutrient deficiency, not only the crop produces lower yields than the potentials, but the plant could not grow vigorously to resistant insect pests and diseases attack [9]. Phosphorous functions both as a part of several key plant structure compounds and as a catalysis in the conversion of various biochemical reactions in plants. Similarly, Potash is one of sixteen essential nutrient elements required for plant growth and reproduction [10].

In Pakistan, the okra is grown throughout the country [11]. Although climatic conditions are quite favorable of its cultivation but the average green pod yield per unit area in the country is low as compared with several other countries [12]. There are many reasons for low yield in Okra, including genetic factors, nutritional factors and space available to the plants. Besides the improved cultural practices, there is also need to grow high yielding cultivars to increase green pod yield per unit area. [5] Observed that number of pods per plant and weight of pods per plant significantly increased the yield of okra hybrids. [13] reported that cultivar Malav-27 gave maximum number of picking (27.80), pods per plant (26.22), fruit diameter $(1.46 \mathrm{~cm})$, plant height $(1.48 \mathrm{~m})$, yield hectare ${ }^{-}$ 1 (14.57 tons) and took minimum days to emerge (10.89). Sachan [14] reported okra Anamika and Saatdhari as the most promising Okra cultivars. Saatdhari recorded the highest pod weight (13.1g) and green pod yield (119.17 kg ha-1). Katung [15] found that the variety 'White velvet' produced more fruits than 'ExBorno'. Jamala et al. [8] recorded the highest fresh fruit yield of 10.7 tons $\mathrm{ha}^{-1}$ in improved okra cultivar as compared to local that recorded the lowest fresh fruit yield of 4.9 tons ha ${ }^{-1}$. Falusi et al. [16] found that the number of leaves plant ${ }^{-1}$ and plant height at maturity and number of seeds pod $^{-1}$ were significantly highest in V35 and Jokoso than in NH4. Some local cultivars are cultivated in this area for the last several decades. But these cultivars give no reasonable yields and are also affected by different insects and diseases.

So there is an intense need to introduce some new cultivars with higher yield and quality product. In view of the facts mentioned above, five okra cultivars were tested under the agro-climatic conditions of Tandojam for their growth and yield performance.

\section{Materials and Methods}

The field experiment was conducted during the year 2015 at experimental and demonstration Orchard, Department of Horticulture, Sindh Agriculture University Tandojam. The okra varieties viz., Sabz Pari, Punjab Selection, Anmol, Sharmeeli and Anamika were evaluated for growth and yield attributes. The experiment was laid out in a three Replicated Randomized Complete 
Block Design (RCBD) with plot size of $2 \mathrm{~m} \mathrm{x}$ $2.5 \mathrm{~m}\left(5 \mathrm{~m}^{2}\right)$. The soil of the experimental site was analyzed for basic physicochemical properties and texture. According to the soil analysis report, sand, silt and clay ratios in the experimental soil were 16.34, 46.66 and 37.00 percent, respectively and recognized as silty clay loamy in texture. The soil $\mathrm{pH}$ determined at 7.98, CaCO3 6.98 percent, EC $1.91 \mathrm{dSm}-1$, organic matter 0.530 percent, available P $7.11 \mathrm{mg} \mathrm{kg}-1$, and total P 832.12 ppm. Accordingly the soil was deficient of organic matter and available $\mathrm{P}$; while $\mathrm{pH}$ and EC levels were within acceptable limits. Initially, the land was prepared as per the recommended tillage practices. Deep plowing was done in the off-season to remove the hard pan of the soil and then leveling was done. After leveling the experimental fields were irrigated as soaking dose and when the land came in condition, it was plowed again and rotavator was operated. After completion of land preparation process, the ridges were prepared for sowing of okra varieties. Five Okra varieties Sabz Pari, Punjab Selection, Anmol, Sharmeeli, Anamika were evaluated for the growth and yield performance.

The Nitrogen $\left(100 \mathrm{~kg} \mathrm{ha}^{-1}\right)$ were applied in the form of urea, phosphorus $\left(75 \mathrm{~kg} \mathrm{ha}^{-1}\right)$ in the form of single super phosphate (SSP) and Potash $\left(75 \mathrm{~kg} \mathrm{ha}^{-1}\right)$ in the form of sulphate of potash (SOP). All Phosphorous and potash along with $1 / 3^{\text {rd }}$ of Nitrogen were applied at the time of ridges preparation, while the remaining Nitrogen was given in two equal splits at 15 days interval. Observations Plant height $(\mathrm{cm})$, Branches plant ${ }^{-1}$, Pods plant ${ }^{-1}$, Single pod weight (g), Weight of pods plant ${ }^{-}$ ${ }^{1}(\mathrm{~g})$, Pod length $(\mathrm{cm})$, Pod yield $\left(\mathrm{kg} \mathrm{ha}^{-1}\right)$ were recorded.

The data recorded on above characters was subjected to statistical analysis of variance following Gomez and Gomez (1984) and L.S.D. test was applied to discriminate the superiority of treatments means. The analysis of the data was conducted by the means of MSTAT-C Statistical Package for personal computers.

\section{Results}

The present experiment was conducted during 2015 at experimental and demonstration Orchard, Department of Horticulture, Sindh Agriculture University Tandojam. The okra varieties viz., Sabz Pari, Punjab Selection, Anmol, Sharmeeli and Anamika were evaluated for growth and yield indices at climatic conditions of Tandojam. The observations were recorded on plant height $(\mathrm{cm})$, branches plant ${ }^{-1}$, pods plant $^{-1}$, single pod weight $(\mathrm{g})$, weight of pods plant $^{-1}$, pods length $(\mathrm{cm})$ and pod yield $(\mathrm{kg}$ $\mathrm{ha}^{-1}$ ). The data on the above characters of okra are presented in Tables 1 . The results for the above characters in view of the statistical analysis are interpreted under respective subheadings in the following pages:

\section{Plant height $(\mathbf{c m})$}

The analysis of variance demonstrated considerably remarkable variation in plant height $(\mathrm{cm})$ of okra among varieties at probability level $(\mathrm{P}<0.05)$. However, LSD test indicates significant $(\mathrm{P}<0.05)$ difference in plant height $(\mathrm{cm})$ between varieties ' $\mathrm{Sabz}$ Pari, Sharmeeli and Anamika' but nonsignificant $\quad(\mathrm{P}>0.05)$ between varieties 'Punjab Selection and Anmol'.

The information (Table 1) indicates that tallest plant height were examined for variety 'Sabz Pari' with average plant height (87.47 $\mathrm{cm}$ ) followed by variety 'Punjab Selection', 'Anmol' and 'Sharmeeli' resulted average plant height of $(83.57 \mathrm{~cm}, 82.87 \mathrm{~cm}$ and $77.53 \mathrm{~cm})$. The smallest plant height $(74.67$ $\mathrm{cm})$ was determined for okra variety 'Anamika'. The results indicate that okra variety 'Sabz Pari' upshot greatest plant height as compared to rest of the okra varieties.

\section{Branches plant ${ }^{-1}$}

The analysis of variance verified greatly incredible dissimilarity in branches plant $^{-1}$ of 
okra between varieties at probability level $(\mathrm{P}<0.05)$. On the other hand, LSD test also designated significant $(\mathrm{P}<0.05)$ difference in branches plant ${ }^{-1}$ among varieties 'Sabz Pari, Punjab Selection, Anmol, Sharmeeli and Anamika'.

The data (Table 1) specify that average maximum branches plant ${ }^{-1}$ were produced by variety 'Sabz Pari' (5.66 plant $^{-1}$ ) followed by variety 'Punjab Selection', 'Anmol' and 'Sharmeeli' resulted (4.72, 4.19 and 3.90 plant $\left.^{-1}\right)$. The minimum branches plant ${ }^{-1}$ (3.55) was noted for okra variety 'Anamika'. The results indicate that okra variety 'Sabz Pari' resulted authoritatively for producing maximum branches plant ${ }^{-1}$ followed by varieties 'Punjab Selection, Anmol, Sharmeeli and Anamika.

\section{Pods plant $^{-1}$}

The analysis of variance confirmed very much inconceivable unlikeness in pods plant ${ }^{-}$ 1 of okra between varieties at probability level $(\mathrm{P}<0.05)$. Likewise, LSD test voted significant $(\mathrm{P}<0.05)$ difference in pods plant ${ }^{-}$ 1 among varieties 'Sabz Pari, Punjab Selection and Anamika, but non-significant $(\mathrm{P}>0.05)$ for varieties 'Anmol and Sharmeeli'.

The records (Table 1) denoted that average maximum pods plant $^{-1}$ were produced by variety 'Sabz Pari' (28.37) followed by variety 'Punjab Selection', 'Anmol' and 'Sharmeeli' resulted (20.62, 18.70 and 1.28). The minimum (13.47 pods plant ${ }^{-1}$ ) was recorded for okra variety 'Anamika'. The consequences point out that okra variety 'Sabz Pari' significantly enhanced pods plant $^{-1}$ as compared to rest of the okra varieties 'Punjab Selection, Anmol, Sharmeeli and Anamika.

\section{Single pod weight (g)}

The analysis of variance signify remarkable variation in single pod weight $(\mathrm{g})$ of okra among varieties at probability level $(\mathrm{P}<0.05)$. Similarly, LSD test nominated significant $(\mathrm{P}<0.05)$ difference in single pod weight $(\mathrm{g})$ among varieties 'Sabz Pari, Punjab Selection, Anmol, Sharmeeli and Anamika. The proceedings (Table 1) represented that average maximum single pod weight were produced by variety 'Sabz Pari' (15.15 g) followed by variety 'Punjab Selection', 'Anmol' and 'Sharmeeli' resulted (13.81 g, $12.18 \mathrm{~g}$, and $10.53 \mathrm{~g}$ ). The minimum weight of single pod $(9.60 \mathrm{~g})$ was noted for okra variety 'Anamika'. The result indicates that okra variety 'Sabz Pari' drastically improved single pod weight (g) as compared to rest of the okra varieties 'Punjab Selection, Anmol, Sharmeeli and Anamika.

\section{Weight of pods plant ${ }^{-1}$}

The analysis of variance verified greatly incredible dissimilarity in weight of pods plant $^{-1}$ of okra among varieties at probability level $(\mathrm{P}<0.05)$. On the other hand, LSD test also designated significant $(\mathrm{P}<0.05)$ difference in weight of pods plant ${ }^{-1}$ among varieties 'Sabz Pari, Punjab Selection and Anmol, But non-significant $(\mathrm{P}>005)$ for varieties 'Sharmeeli and Anamika'.

The data (Table 1) specify that average maximum weight of pods plant ${ }^{-1}$ were produced by variety 'Sabz Pari' (252.67) followed by variety 'Punjab Selection', 'Anmol' and 'Sharmeeli' resulted (211.67, 179.67 and 163.67 plant $^{-1}$ ). The minimum weight of pods plant ${ }^{-1}$ was noted for okra variety 'Anamika' with average weight of pods (157.00). The results indicate that okra variety 'Sabz Pari' resulted authoritatively for producing maximum weight of pods plant $^{-1}$ followed by varieties 'Punjab Selection, Anmol, Sharmeeli and Anamika.

\section{Pod length $(\mathrm{cm})$}

The analysis of variance demonstrated considerably remarkable variation in pod length $(\mathrm{cm})$ of okra among varieties at probability level $(\mathrm{P}<0.05)$. However, LSD test indicates significant $(\mathrm{P}<0.05)$ difference in pod height $(\mathrm{cm})$ among varieties ' $\mathrm{Sabz}$ Pari, Punjab Selection, Anmol, Sharmeeli and Anamika'. 
The information (Table 1) indicates that maximum pod length were examined for variety 'Sabz Pari' with average pod length $(6.37 \mathrm{~cm})$ followed by variety 'Punjab Selection', 'Anmol' and 'Sharmeeli' resulted average pod length of $(5.79,5.12$ and 4.80 $\mathrm{cm})$. Minimum pod length $(3.76 \mathrm{~cm})$ was determined for okra variety 'Anamika'. The results indicate that okra variety 'Sabz Pari' upshot maximum pod length as compared to rest of the okra varieties.

\section{Pod yield (kg ha-1)}

The analysis of variance verified greatly incredible dissimilarity in pod yield $\left(\mathrm{kg} \mathrm{ha}^{-1}\right)$ of okra varieties at probability level $(\mathrm{P}<0.05)$. On the other hand, LSD test also designated significant $(\mathrm{P}<0.05)$ difference in pod yield $\left(\mathrm{kg} \mathrm{ha}^{-1}\right)$ among varieties ' $\mathrm{Sabz}$ Pari, Punjab Selection, Anmol, Sharmeeli and Anamika'.

The data (Table 1) specify that average highest pod yield were produced by variety 'Sabz Pari' (12733 kg ha ${ }^{-1}$ ) followed by variety 'Punjab Selection', 'Anmol' and 'Sharmeeli' resulted (9800, 7500 and 6467 $\left.\mathrm{kg} \mathrm{ha}^{-1}\right)$. Lowest pod yield $\left(5750 \mathrm{~kg} \mathrm{ha}^{-1}\right)$ was noted for okra variety 'Anamika'. The results indicate that okra variety 'Sabz Pari' resulted authoritatively for producing maximum pod yield $\left(\mathrm{kg} \mathrm{ha}^{-1}\right)$ followed by varieties 'Punjab Selection, Anmol, Sharmeeli and Anamika.

Table 1. Plant height (cm), Branches plant ${ }^{-1}$, Pods plant ${ }^{-1}$, Single pod Weight $(\mathrm{g})$, Weight of pods plant $^{-1}(\mathrm{~g})$, Pod length $(\mathrm{cm})$ and Pod yield (kg ha-1) of okra varieties under climatic conditions of Tandojam

\begin{tabular}{|c|c|c|c|c|c|c|c|}
\hline Varieties & $\begin{array}{c}\text { Plant } \\
\text { height } \\
(\mathbf{c m})\end{array}$ & $\begin{array}{c}\text { branches } \\
\text { plant-1 }\end{array}$ & $\begin{array}{c}\text { Pods } \\
\text { plant-1 }\end{array}$ & $\begin{array}{c}\text { Single } \\
\text { pod } \\
\text { Weight } \\
(\mathbf{g})\end{array}$ & $\begin{array}{c}\text { Weight } \\
\text { of pods } \\
\text { plant-1 } \\
(\mathbf{g})\end{array}$ & $\begin{array}{c}\text { Pod length } \\
(\mathbf{c m})\end{array}$ & $\begin{array}{c}\text { Pod yield } \\
\text { (kg ha-1) }\end{array}$ \\
\hline Anmol & $82.87 \mathrm{~b}$ & $4.19 \mathrm{c}$ & $18.70 \mathrm{c}$ & $12.18 \mathrm{c}$ & $179.67 \mathrm{c}$ & $5.12 \mathrm{c}$ & $7500 \mathrm{c}$ \\
\hline Sabz Pari & $87.47 \mathrm{a}$ & $5.66 \mathrm{a}$ & $28.37 \mathrm{a}$ & $15.15 \mathrm{a}$ & $252.67 \mathrm{a}$ & $6.37 \mathrm{a}$ & $12733 \mathrm{a}$ \\
\hline Anamika & $74.67 \mathrm{~d}$ & $3.55 \mathrm{~d}$ & $13.47 \mathrm{~d}$ & $9.60 \mathrm{e}$ & $157.00 \mathrm{~d}$ & $3.76 \mathrm{e}$ & $5750 \mathrm{e}$ \\
\hline $\begin{array}{c}\text { Punjab } \\
\text { Selection }\end{array}$ & $83.57 \mathrm{~b}$ & $4.72 \mathrm{~b}$ & $20.62 \mathrm{~b}$ & $13.81 \mathrm{~b}$ & $211.67 \mathrm{~b}$ & $5.79 \mathrm{~b}$ & $9800 \mathrm{~b}$ \\
\hline Sharmeeli & $77.53 \mathrm{c}$ & $3.90 \mathrm{~cd}$ & $17.28 \mathrm{c}$ & $10.53 \mathrm{~d}$ & $163.67 \mathrm{~d}$ & $4.80 \mathrm{~d}$ & $6467 \mathrm{~d}$ \\
\hline S.E.t & 0.3793 & 0.1622 & 0.6269 & 0.1853 & 3.0350 & 0.0600 & 265.73 \\
\hline LSD 0.05 & 0.8746 & 0.3739 & 1.4457 & 0.4273 & 6.9987 & 0.1383 & 612.77 \\
\hline
\end{tabular}

\section{Discussion}

\section{Plant height}

Maximum plant height were examined for variety 'Sabz Pari' followed by variety 'Punjab Selection', 'Anmol' and 'Sharmeeli'. Minimum plant height was determined for okra variety 'Anamika'. The results indicate that okra variety 'Sabz Pari' upshot greatest plant height as compared to rest of the okra varieties. Rani et al. [17] who examined okra cultivars and concluded that Arka Anamika had superior performance with respect to plant height. Studies carried out by Gowda et al. [10] evaluated okra cultivars Arka Anamika, Varsha and Vishal and reported that Varsha had the maximum plant height. Bangulzai [18] Examined okra varieties Pusa Swani, Mirpurkhas-I and Ahmedabadi and reported that Mirpurkhas-I showed its superiority in plant height over Ahmedabadi and Pusa Swani, while Ahmedabadi remained slightly better in plant height.

Branches plant ${ }^{-1}$

Maximum branches plant ${ }^{-1}$ were produced by variety 'Sabz Pari' followed by variety 'Punjab Selection', 'Anmol' and 'Sharmeeli'. The minimum branches plant ${ }^{-1}$ 
was noted for okra variety 'Anamika'. The results indicate that okra variety 'Sabz Pari' resulted authoritatively for producing maximum branches plant $^{-1}$ followed by varieties 'Punjab Selection, Anmol, Sharmeeli and Anamika. Khokhar [19] Reported that okra variety 'Emerald' produced significantly greater values for number of branches (7.57) as compared to rest of the okra cultivars. Patel and Singh [20] Planted okra cv. Pusa Sawani and achieved highest branches per plant. Mohapatra et al. [21] Found that okra cv. Utkal Gaurav performed maximum in terms of number of branches per plant

\section{Pods plant ${ }^{-1}$}

Maximum pods plant $^{-1}$ were created by variety 'Sabz Pari' followed by variety 'Punjab Selection', 'Anmol' and 'Sharmeeli'. The minimum pods plant ${ }^{-1}$ was recorded for okra variety 'Anamika'. The consequences point out that okra variety 'Sabz Pari' significantly enhanced pods plant $^{-1}$ as compared to rest of the okra varieties 'Punjab Selection, Anmol, Sharmeeli and Anamika. Khokhar [19] reported that okra variety 'Emerald' produced significantly greater values for pods per plant (36.33) as compared to rest of okra genotypes. Patel and Singh [20] Planted okra cv. Pusa Sawani and achieved highest pod per plant. Mohapatra et al. [21] found that okra cv. Utkal Gaurav performed maximum in terms of pods per plant.

\section{Single pod weight (g)}

Maximum single pod weight was produced by variety 'Sabz Pari' followed by variety 'Punjab Selection', 'Anmol' and 'Sharmeeli'. The minimum weight of single pod was noted for okra variety 'Anamika'. The result indicates that okra variety 'Sabz Pari' drastically improved single pod weight (g) as compared to rest of the okra varieties 'Punjab Selection, Anmol, Sharmeeli and Anamika. Khokhar [19] recorded maximum weight of single pod for okra variety
'Emerald' as compared to rest of okra genotypes. [20] Noted maximum weight of single pod for variety Pusa Sawani. Mohapatra et al. [21] Found that okra cv. Utkal Gaurav performed maximum in terms of single weight of pod.

Weight of pods plant ${ }^{-1}$

Maximum weight of pods plant ${ }^{-1}$ was produced by variety 'Sabz Pari' followed by variety 'Punjab Selection', 'Anmol' and 'Sharmeeli'. The minimum weight of pods plant $^{-1}$ was noted for okra variety 'Anamika' with average weight of pods. The results indicate that okra variety 'Sabz Pari' resulted authoritatively for producing maximum weight of pods plant ${ }^{-1}$ followed by varieties 'Punjab Selection, Anmol, Sharmeeli and Anamika. Khokhar [19] recorded maximum weight of pods per plant for okra variety 'Emerald' as compared to rest of okra genotypes. Patel and Singh [20] Noted maximum weight of pods per plant for variety Pusa Sawani. Mohapatra et al. [21] found that okra cv. Utkal Gaurav performed maximum in terms of weight of pods per plant.

\section{Pod length (cm)}

Tallest pod length was examined for variety 'Sabz Pari' with average pod length (6.37 $\mathrm{cm})$ followed by variety 'Punjab Selection', 'Anmol' and 'Sharmeeli' resulted average pod length of $(5.79,5.12$ and $4.80 \mathrm{~cm})$. The smallest pod length of $(3.76 \mathrm{~cm})$ was determined for okra variety 'Anamika'. The results indicate that okra variety 'Sabz Pari' upshot greatest pod length as compared to rest of the okra varieties. Rani et al. [17] Recorded maximum pod length for okra variety Pusa Sawani; while Arka Anamika had superior performance with respect to pod length as compared to cultivar Pusa Sawani. Studies carried out by Gowda et al. [10] Evaluated okra cultivars Arka Anamika, Varsha and Vishal and reported that Varsha had the maximum pod length. Bangulzai [18] Examined okra varieties Pusa Swani, 
Mirpurkhas-I and Ahmedabadi and reported that Mirpurkhas-I showed its superiority over Ahmedabadi and Pusa Swani, particularly in pod length, while Ahmedabadi remained slightly better in pod length. Khokhar [19] reported that okra variety 'Emerald' produced significantly greater values for pod length $(8.08 \mathrm{~cm})$

\section{Pod yield (kg ha-1)}

Maximum pod yield were produced by variety 'Sabz Pari' followed by variety 'Punjab Selection', 'Anmol' and 'Sharmeeli'. The minimum pod yield was noted for okra variety 'Anamika'. The results indicate that okra variety 'Sabz Pari' resulted authoritatively for producing maximum pod yield $\left(\mathrm{kg} \mathrm{ha}^{-1}\right)$ followed by varieties 'Punjab Selection, Anmol, Sharmeeli and Anamika. These findings are in accordance with Amjad et al. [12] who reported that the pod yield ha${ }^{1}$ was highest (19.41 tons) in case of okra cv. Sabz Pari. Bandyopadhyay et al. [9] reported that okra cv. Parbhani Kranti plants gave highest yield as compared to rest of the tested varieties. However, the variation in the results may be associated with the varieties used in various researches may have typically different genotypes suitable for the particular environmental conditions.

\section{Conclusion}

It was concluded that the variety 'Sabz Pari' showed highest performance in all studded parameters followed by okra varieties Panjab selection, Anmol, and Sharmeeli. While the Okra variety Anamika showed least figure for pod yield. On the basis of present findings, it is recommended that okra variety 'Sabz Pari' may be grown for achieving optimum results in climatic conditions of Sindh, Pakistan.

\section{Authors' contributions}

Conceived and designed the experiments: $S$ Faisal \& FM Bangulzai, Performed the experiments: S Faisal \& FM Bangulzai, Analyzed the data: N Ahmed, Contributed reagents/ materials/ analysis tools: NA
Alizai, S Ahmed \& FM Bangulzai, Wrote the paper: S Faisal \& FM Bangulzai.

\section{References}

1. Rajesh J, Prasad VM \& Kerketta A (2018). Evaluation of Different Okra (Abelmoschus esculentus L.) Moench] Hybrids for Yield and Yield Attributes under Allahabad Agro-climatic Condition. Inter J Pure Appl Biosci 6(5): 1343-1346.

2. Tripathi KK, Govila OP, Warrier R \& Ahuja V (2011). Biology of Abelmoschus esculentus L. (Okra). Seri of Crop Spfic Biol Doc, pp. 35.

3. Osman EA (2005). Field trials for the control okra leaf curl virus disease. Uni of Khartoum MSc Thesis.

4. Demrany AM \& Faraq IA (1994). An evaluation of growth, yield and quality of some okra cultivars. Assi J Agric Sci 25: 57-70.

5. Khan FA, Jalal S, Ghaffoor A \& Khan KW (2002). Evaluation of different cultivars of okra under the agro-climatic conditions of Dera Ismail Khan. Asian J of Plan Sci 1(6): 663-664.

6. Chaudhary UN, Khanvilkar MH, Desai SD, Prabhudesai SS, Chaudhary PR \& Raut VU (2006). Performance of different okra hybrids under North Konkan coastal zone of Maharashtra. $J$ of Soil \& Crops 16(2): 375-378.

7. Rahman K, Waseem K, Kashif M, Jilani MS, Kiran M, Ghazanfarullah \& Mamoon-Ur-Rashid M (2012). Performance of different Okra (Abelmoschus esculentus L.) Cultivars under the Agro-climatic conditions of Dera Ismail Khan. Pak J of Sci 64(4): 316-319.

8. Jamala GY, Boni PG, Abraham P \& Musa AM (2011). Soil Status and yield response of different varieties of Okra (Abelmoschus esculentus (L.) Moench) grown at Mubi flood plain, North 
Eastern, Nigeria. J Agric Biotec \& Sust Deve 3(7): 120-125.

9. Bandyopadhyay S, Chakraborty $\mathrm{T}$ \& Poddar P (2001). Effect of polythene and organic mulching under different levels of manuring practices of growth and seed yield of okra Abelmoschus esculentus (L.) Moen Envi \& Eco 19(2): 261-264.

10. Gowda MCB, Krishnappa KS, Gowda MC \& Puttaraju TB (2002). Effect of NPK levels on seed production, dry matter, nutrient accumulation and uptake of nutrients in okra. S Indi Horti 50(4/6): 543-549.

11. Baloch AF (1994). Vegetable Crops: Horti Nati Book Foun Isla, pp. 529-531.

12. Amjad M, Anjum MA, \& Ali A (2001). Impact of phosphorus and planting geometry on growth, yield and quality of green pods in okra. Inter $J$ of Agric \& Biol 3(4): 341-344.

13. Hussain S, Muhammad S, Noor A, Shah A \& Iqbal Z (2006). Response of Okra (Abelmoschus esculentus) Cultivars to different sowing times. J of Agric \& Bio Sci 1(1): 55-59.

14. Sachan VK (2006). Performance of okra (Abelmoschus esculentus L.) varieties in mid hills of Sikkim. Oris $J$ of Horti 34(2): 131-132.

15. Katung MD (2007). Productivity of Okra varieties as influenced by seasonal changes in Northern Nigeria. Not Bot Hort Agro bot Cluj 35(1): 65-71.

16. Falusi OA, Dangana MC, Daudu OY, \& de-Silva JAT (2012). Studies on morphological and yield parameters of three varieties of Nigerian okra [Abelmoschus esculentus (L.) Moen J of Horti \& Forest 4: 126-128.

17. Rani KR, Sankar CR \& Prasad DM (1999). Study on growth and yield of okra cultivars in response to fertilizer levels during hot weather period. Adva in Hort \& Forest 7: 101-105.

18. Bangulzai KA (2005). Seed production of okra, Abelmoschus esculentus L. varieties as influenced by different NP levels. M.Sc. Thesis subm to SAU T jam, pp.1-80.

19. Khokhar J (2003). Inter and intra row spacing effects on the growth and productivity of okra, Abelmoschus esculentus L. M.Sc. Thesis subm to SAU T Jam, pp. 1-72.

20. Patel KD \& Singh SP (1991). Effect of CCC and plant density on plant height and yield components in okra, Abelmoschus esculentus L. Oris $J$ of Hort 19(1-2): 14-21.

21. Mohapatra SK, Maharana T \& Dash FM (2001). Effect of spacing, clipping and plucking on seed production in okra. Oris J of Hort 29(2): 100-102. 